\title{
Case study: Examples of Wooden Vernacular Architecture - Turkish Houses in Western Anatolia
}

\author{
Özgül Yilmaz Karaman ${ }^{1}$, Mine Tanaç Zeren² \\ ${ }^{1}$ Department of Architecture, Dokuz Eylul University, Izmir, Turkey \\ ozgul.yilmaz@deu.edu.tr \\ ${ }^{2}$ Department of Architecture, Dokuz Eylul University, Izmir, Turkey \\ mine.tanac@deu.edu.tr
}

\begin{abstract}
Wooden material is described as the oldest construction material along with stone. In the historical process, especially for the buildings of shelter, timber construction components are seen to be used as primary and indispensable structural system components in different geographies of the world as well as Anatolia. This paper focuses on timber-frame structures of four different settlements from Western Anatolia. It is aimed to analyze the traditional techniques, in order to transmit our cultural heritage to the next generations, as well as obtaining some data on construction techniqes to be used for creating alternative solutions to the house production of today.
\end{abstract}

Keywords: Traditional Turkish Houses, Timber Structures, Traditional Construction Techniques, Timber Housing Technology, Western Anatolia.

\section{INTRODUCTION}

Timber is one of the most important construction materials of Traditional Turkish House in Anatolia. These traditional Turkish houses are an important part of our cultural inheritance with its architectural style and timber components (projection, fringe etc.) and craftsmanship. In addition, in the houses which have not been built by an engineer or architect (non-engineered structures), there are many principles that can be considered today as well in terms of effective use of the material.

With the description of Reha Günay, the timber which is the main structural material of Turkish House, determines the geographical borders of Turkish House (Günay, 1998, p. 30). In this context, even though some differences are seen between the construction techniques and the sizes of timber components and combination details, in almost every region in Anatolia excluding the ones where finding timber is very difficult, timber is one of the main construction material used.

Timber housing is very common particularly in North and North West Anatolia almost all of which is the seismic zone of 1st degree and the entire building can be built by timber material.

On a timber building, the production of the structural system components, secondary building components and even surface coatings with timber material is possible. In another word, all horizontal and vertical loads which affect the structure system are conveyed up to the base with these timber components. 
The components which are not purposed for carrying load like timber outer coating and surface coating, on the other hand, are used for the task of creating a shell that protects the spaces from the physical effects as well as the components to increase the resistance against the horizontal forces like wind and earthquake load within the system. However, timber construction materials can be used with massive materials like adobe, stone or brick in house production depending on many factors like the availability of the timber material, a more economic manufacturing, building physics requirements, life conditions in the region and cultural aspects from the traditional methods to today. In another word, "mixed" constructions have to be produced. While timber is used as construction material in the regions where the availability is short, the construction techniques in which small timber components or stone, adobe, brick or soil filling (hımıs, bagdadi etc.) on the façade and surface foundations of the houses have been developed.

Timber frame system that rises over the ground floor walls generally made with stone, composes the first floor (sometimes second or third depending on the size of the house) and mostly the main living rooms of traditional Turkish house for the reasons like climate factors, protecting timber from humidity, increasing fire resistance and in the context of regional material resources and the effects of traditional life style (for example intimacy requirements). Besides the frame system, it is seen that timber construction elements are used in masonry walls and horizontal construction components like beam and lintel have significant functions against the earthquake loads [1].
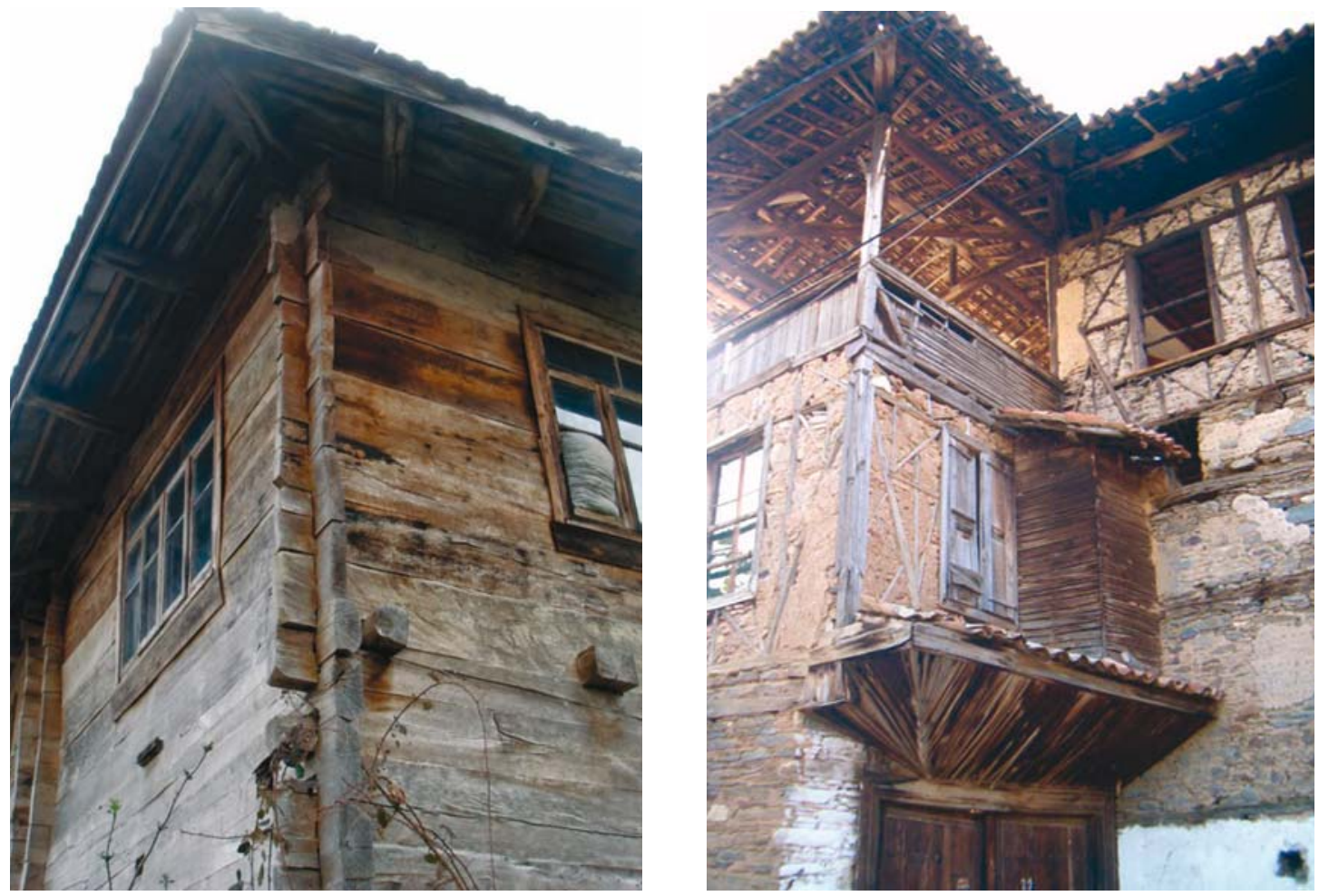

Fig. 3. Log House from Zonguldak, , Gökçebey, Herkime (North Anatolia)(web 1), Timber Framed House from Birgi (Western Anatolia) 


\section{PROPERTIES OF TRADITIONAL TURKISH HOUSE IN WEST ANATOLIA}

As described above, the use of timber especially as structural system component can be seen in many various ways in the geography of Anatolia. Generally it is classified according to the regions with similar climate and topographical properties as well. In this context, under the scope of this work, the properties of Turkish house in West Anatolia are examined. The regions selected under the field work are the traditional settlements of Kula, Mugla, Bayindir and Birgi.

A line passing through Çanakkale and Balıkesir in the North and Uşak and Eğirdir in the East and reaches to Antalya in the South draws the borders of the houses in West Anatolia. A large part of the region was occupied during the Independence War and Aydin and Manisa which are two of the most important settlements were burned in a large extent. However there are some regions which are located little away from the city center and protect their texture as they were. In this sense, the best examples of Turkish houses protected in the region are encountered in Kula, Soma, Tire, Ödemiş, Bayındır, Birgi, Muğla, Milas and Bergama [2].

Houses in the region are located in a courtyard, which is surrounded by high courtyard walls to provide privacy to the house. The ground floor is used for service facilities such as barns, depots and also it is surrounded by thick stone walls and these facility rooms usually have no openings to the street. All the openings of the house are viewed from the courtyard, while rooms located on the first or second floor can also have openings towards the street. North facades of the houses have solid surfaces to protect the interior of the houses from cold, and South facades have open surfaces to obtain sun and breeze for the inside of the houses. All the rooms located in the first and the second floors are opened towards a semi-open space called a "Sofa" (the distribition hall that is used as the main living space for the family during day-time as well). Most of the houses have a space organization with outer sofa $\left.{ }^{1}\right]$ which has a strong relation with the courtyard due to the warm climate conditions.

Shortly, ground floor closed towardsthe street with a stone or adobe wall and an upper floor which sits on either load bearing stone walls or timber studs characterizes the house type generally seen in region. The upper floor(s), which are built by timber frame construction system include(s) living rooms. Usually, the number of the rooms differs depending on the size of family living in the house. The rooms are planned with square or square like forms and are about $12-15 \mathrm{sqm}$; the height of the room is approximately 3 meters. One of the rooms serves as the main one and is called the "Main Room". This main room may differ from other rooms not only because having larger dimensions but also because it owns a projection towards the street.

In Manisa-Kula an important settlement of the region, a plan scheme with outer sofa was applied by the middle of 19th century and then the plan with inner and middle hall started to be used. There were structures like the barn, cellar and kitchen at the lower floor of Kula houses which generally have two floors. In some houses with outer Sofa, a mezzanine was built between the lower and upper parts for living during the winter. The plan type of a mansion with outer Sofa and two rooms and the plan type of a mansion with outer hall and "eyvan" (a private

1 Turkish plan typology was firstly classified by S.H.Eldem due to the spatial organization of Sofa (Hall) spaces, as Outer-Inner-Central Sofa typed houses (Eldem 1955-1972)(Eldem 1984). Eldem defines the "Turkish House" according to the plan type of the piano nobile-the first floor of the main building of the dwelling unit. The sofa; as a semi-closed or a closed space shared by the members of the family is the basis of the typology (Eruzun 1989, 70). 
space organized between the two rooms as part of the sofa)are the most frequently used plan schemas[3]. Also the examples of "Bas Oda (Main Room)" like in the Houses of Beyler and Zabunlar are encountered.
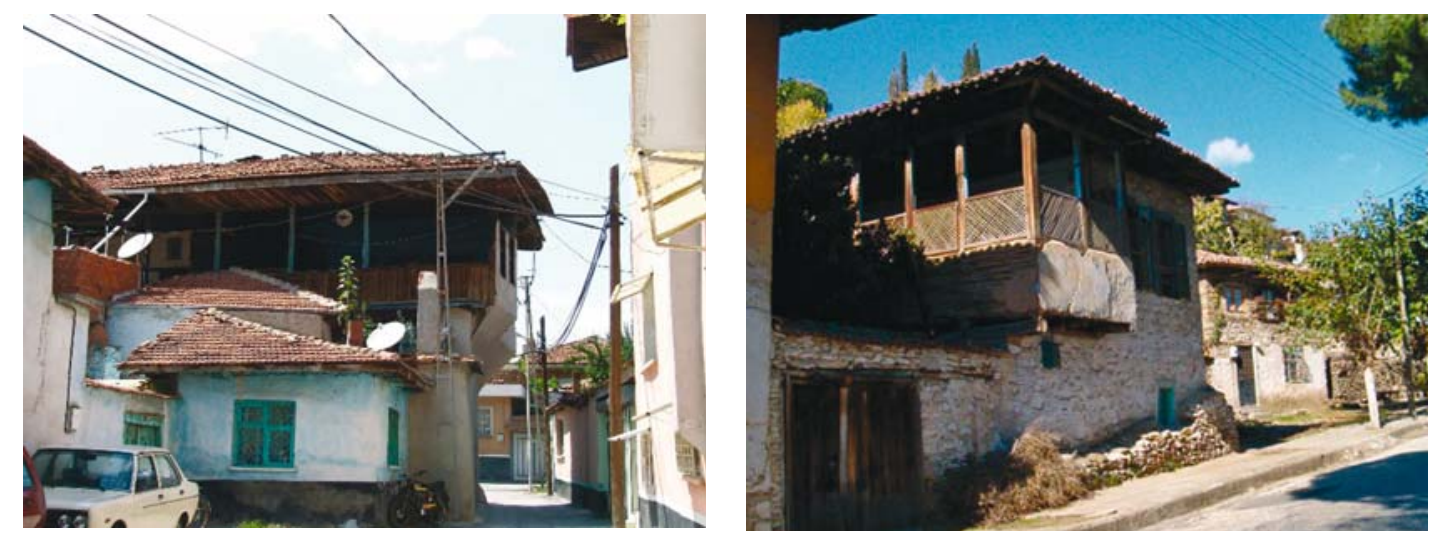

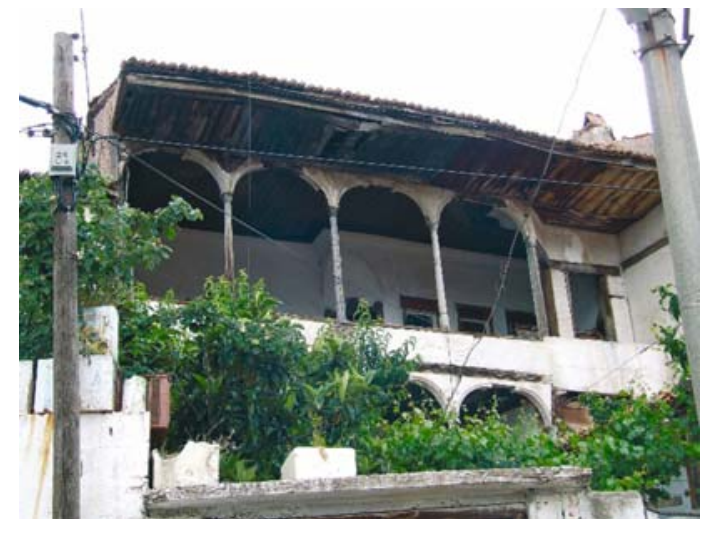

Fig. 4. House with an outer sofa from Kula and Mugla (below)

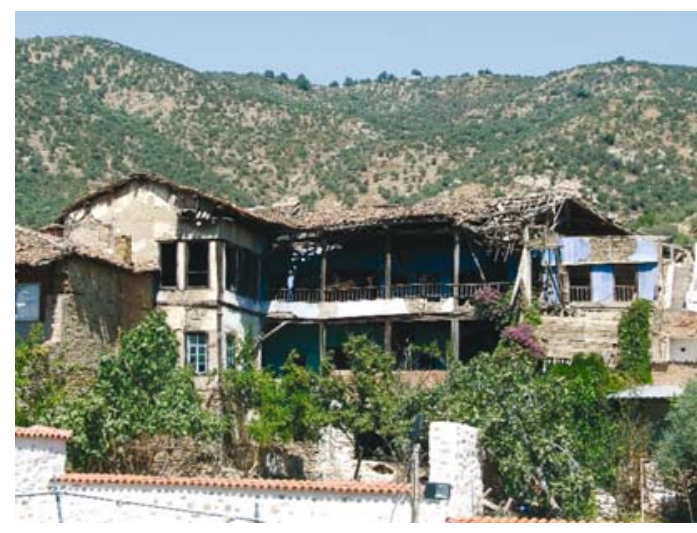

Fig. 5. House with an outer sofa from Birgi and Bayindir (below)

In Muğla and around, the plan type with outer sofa was applied. However this showed some regional differences. Back and side facades of Muğla houses are half-embedded in the ground because of the topography, and were made of stone and have no openings. The front façade faces the courtyard. The houses were generally composed of two floors, the lower floor was used as storage and kitchen. A mezzanine was not created between lower and upper floor and a separate room as main room was not designed on the upper part. There are eyvan in the Sofa of the houses and generally a stair case was established in the parts of eyvan's location[4].

A large majority of Ödemiş-Birgi and Tire houses which shows a similar development with each other have outer sofa. Most frequently used plan schema is the plan type which includes two rooms and eyvan between the rooms. Increase in the room numbers and the "kosk (private space constructed as a raised platform and as part of the Sofa) added to the edge of the Sofa caused the plans to become L and U shape [5].

Bayindir as one of the examples of a Western side cities has an outer sofa space organization. The houses are mostly simple structures due to low income level of the society when compared with other chosen cases. 
Houses were usually built with two stories, upstairs was built as the main living space. Any mid floor between upstairs and downstairs was not built and any main room, either.

\section{DESCRIPTION OF THE TIMBER STRUCTURE OF TRADITIONAL TURKISH HOUSE IN THE WEST ANATOLIA}

Structural systems of Turkish houses in Western Anatolia consist of both masonry and timber as main construction materials. Most of the houses have two floors. Houses are surrounded by load bearing masonry walls mostly made of local stone at the ground floor level, including the courtyard. Most of the time, this heavy stone wall continues through the upper floor at the North side (facade) of the house considering the climate. Masonry walls are supported by horizontal beams called "hatil" at vertical intervals of about 1-1.50 meters. Timber beams placed at particular distances (also today regulations advice that the vertical distance between beams should be 1,2-1,5 meters) help to bind the stone layers together without interrupting the continuity of the masonry construction. In addition to strengthening the masonry structure by connecting the wall surfaces, horizontal beams (hatils) decrease the ratio of height to width and help to determine the location of the first crack. The decay of these timber elements mostly by the effect of water causes the masonry wall to collapse (Hughes 2000).

Upper floor is constructed with timber frame infilled with a technique called as "himis" and plastered or/and covered with small sectioned timber laths and plastered called as "Bagdadi" in Turkey. Himis is a typical timber frame structure in which small pieces of row materials (brick, stone, adobe, etc...) are used as infilling material. And bagdadi is a simply lath and plaster technique where the voids between timber framing members are sometimes filled with lighter materials; the surfaces of the walls are covered by lath and plaster work [6].
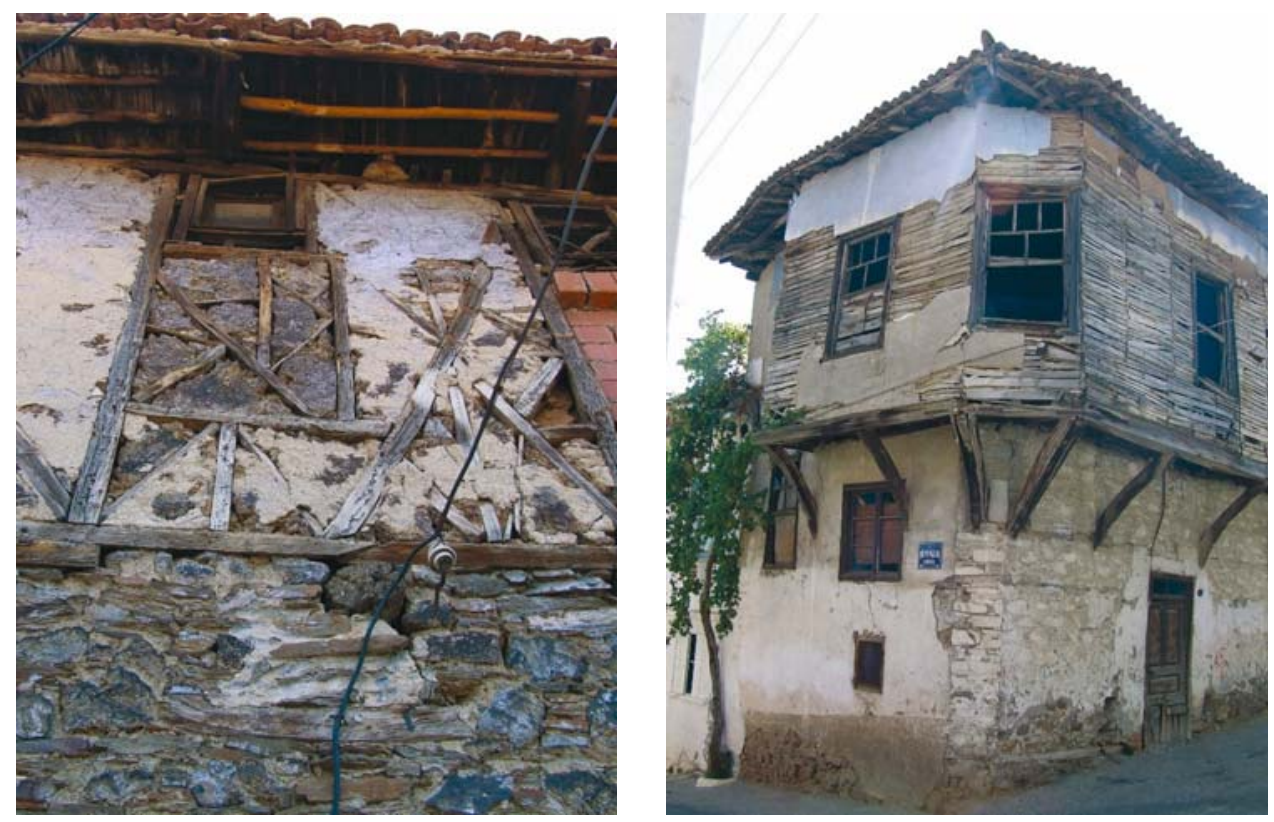

Fig. 6. Himis Technique (Kula) and Bagdadi technique (Bayindir) (right) 
When construction systems and material use in houses of four different selected settlemets are summarised, it is seen that both himis and bagdadi techniques applied to the frame system in all settlements. There are differences in used materials as infills for the himis technique. The infill materials of himis are mainly stone and adobe in Kula, stone in Muğla, adobe in Bayindir and adobe and stone in Birgi. In some cases both techniques can be used in the same house. Use of the timber frame on the first floor helps in decreasing the dead-loads.

Before the construction of the upper floor, the timber wall plates are placed on the inner and outer edges of the ground floor main walls. Also, free-standing posts placed in the semi-open circulation spaces known as "taslik" are connected horizontally to the main beams, forming a base for the upper floors. On the upper floors, posts (studs) and secondary posts are placed on a timber beam which is called as the sole plate (usually $12 / 12 \mathrm{~cm}$ a square section element) as a base on the masonry wall. Usually with a dimension of $10 / 12$ or $12 / 12 \mathrm{~cm}$ posts are usuallymade of yellow pine tree are installed at approx. 1 meter distance-between each other on the sole plate. These posts are connected with a timber beam on the top level as well which is called "top plate". These posts are supported by secondary diagonal timber elements (braces)-of 8/8 $\mathrm{cm}$. In cases of needing openings such as windows or doors, secondary posts are used to obtain the necessary space for the openings. Two secondary timber beams, one at the bottom of the opening and one at the top of the opening (lintel) are used to obtain door or window openings on the surface of the wall. These beams are connected to the main posts with nails. Usually the walls are filled with stone to form the surface.

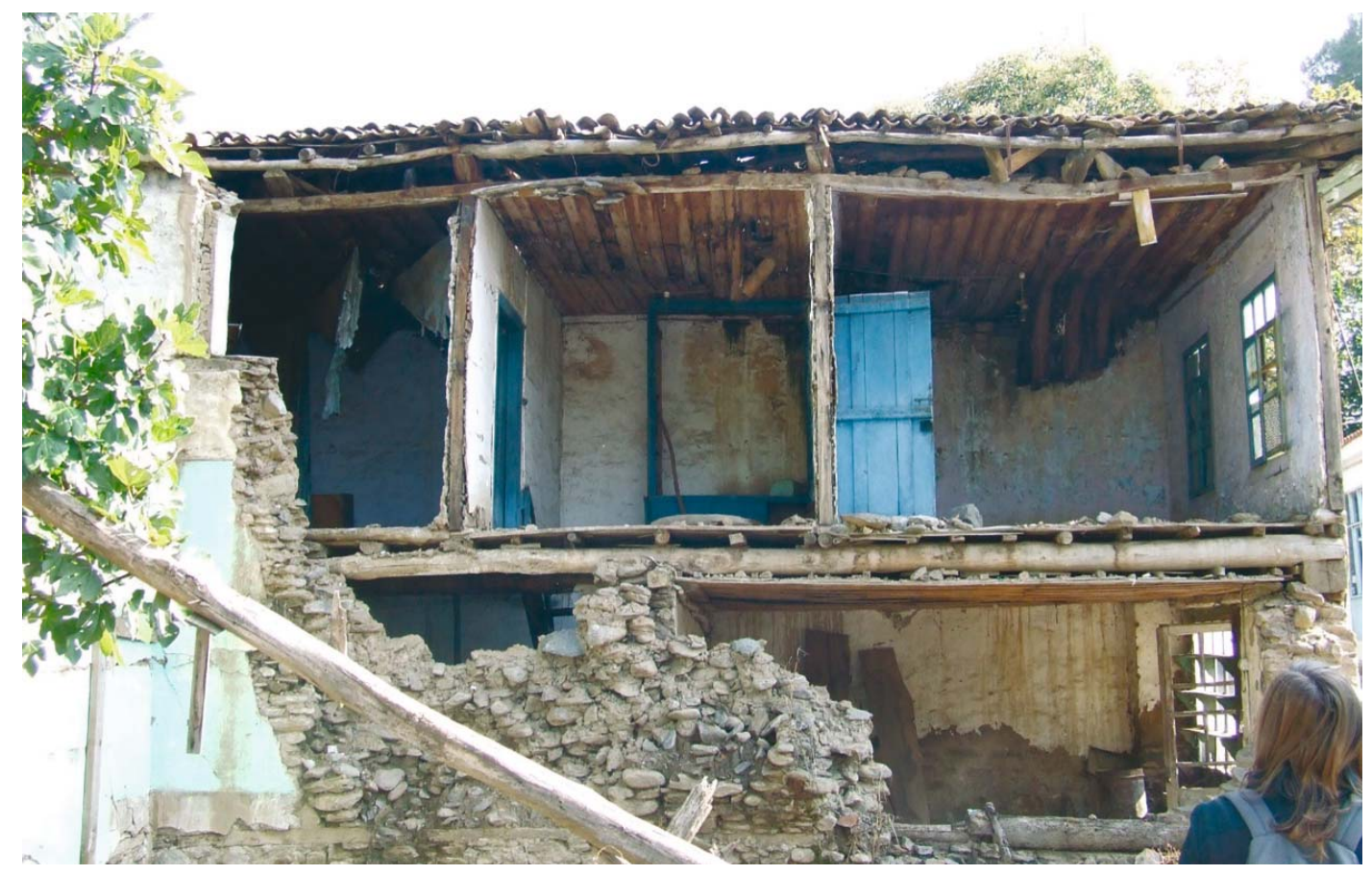

Fig. 7. "Section" of a Traditional Turkish House from Birgi

The construction is plastered by "kitıkl siva (plaster)" which is usually made of mud and tow. In traditional houses the first floor is constructed with timber floor beams that were covered with timber boarding. 
The floor construction can be seen from the ground floor since it does not have a ceiling covering. Floor beams are generally supported by stronger elements in section of about 2.002.50 meters intervals depending on the room size. This floor construction is connected to the masonry ground floor walls by horizontal timber beams called as "sole plate", but sometimes it is seen that floor beams are simply tied to the masonry without any other timber element or insulation layer.

Floor beams (joists) which have usually $8 / 15 \mathrm{~cm}$ dimensions in sections, are spaced at approximately $50 \mathrm{~cm}$ intervals. The spatial dimensions are usually determined according to the size of the available materials, whereas in some larger spaces such as the sofa-the main circulation hall in Ottoman houses - and stony ground where a wide span is required, long timber beams with a relatively larger cross-section (like $15 * 20,20 * 20 \mathrm{~cm}$ ) are used to support the secondary joists. Then the floor is covered with a timber boarding which is nailed to the joists. The floor system that consists of timber joists moving in one direction. Floor has an important role against the lateral forces especially in case of earthquakes since it connects all the masonry walls of the structure as well as the roof.

Another important elements of the first floor are the projections, which are iconic elements of the facades as well. There are numerous examples of projections and they can be different in terms of form, material use and/or construction techniques.
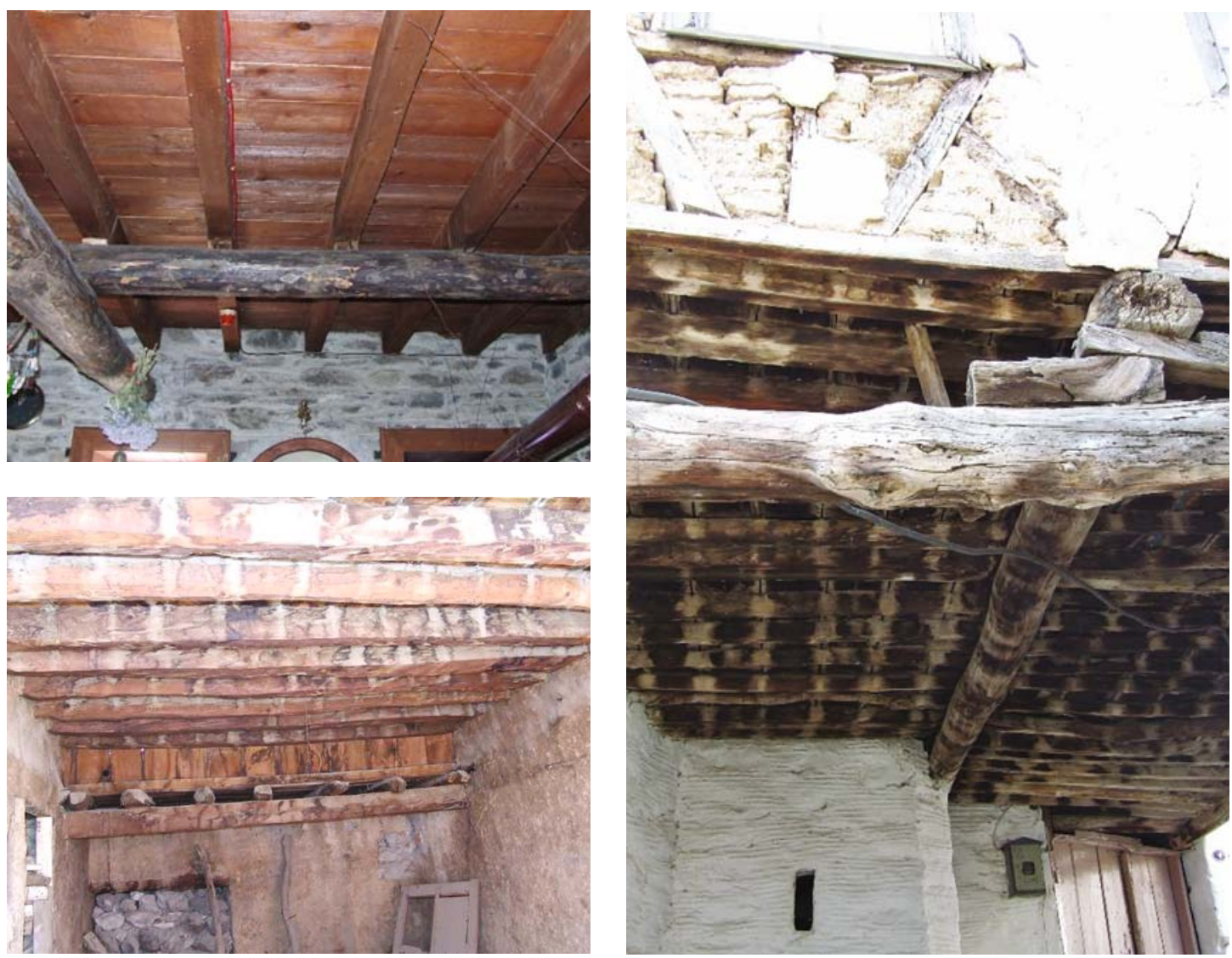

Fig. 8. Floor Constructions of Houses Birgi (left up), Kula (left down) and Bayindir (right) 
To build projection (cikma in Turkish) on the upper floor, the load-bearing elements that carry the projection are constructed according to the type and extension of the projection and put in place at this stage. Main beam(s) is extended and the floor beams placed on/ between them. And the timber cantilever beams are supported by diagonal bracing elements. Floor and roof systems are quite similar, while many types of projections can be seen among the settlements.
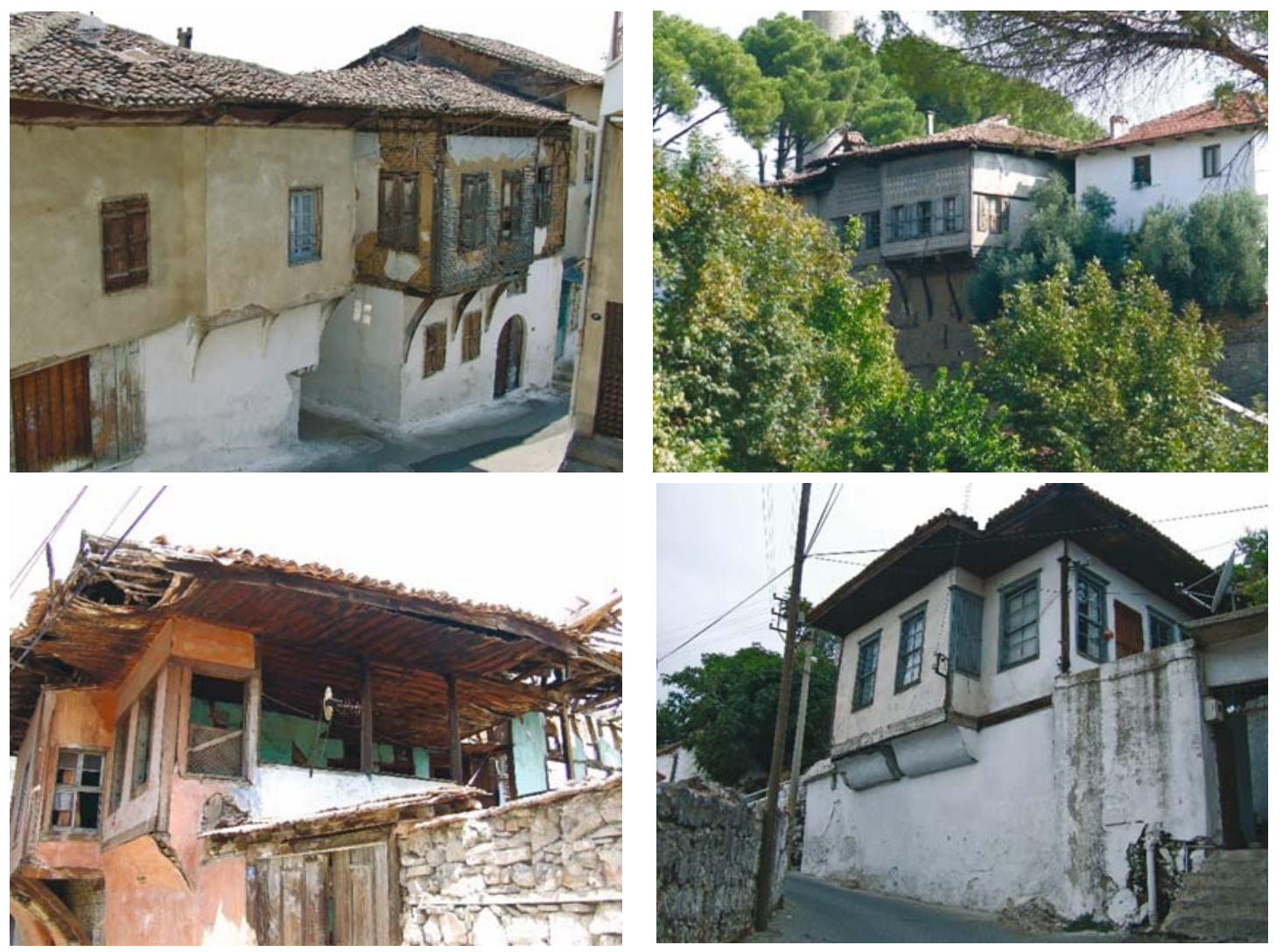

Fig. 9. Different projection types from Bayindir (left up), Kula (Left Down), Birgi (Right Up), Muğla (Right Down)

The outer shell of the house is finished with a timber roof covered with tiles. The use of timber beams and joists are very similar in both floor and roof structure. The main difference is the slope of the roof. To construct the roof, rafters are placed on the top plate of the frame but in some cases a secondary beam-a purlin can be used as well on the top plate. Rafters are connected to the beam on top of the roof. This beam is supported by posts at approximately 200 $\mathrm{cm}$ intervals. The floor rafters are covered with a timber boarding at first, then tiles are placed on this timber layer. In some cases especially in lower income houses rafters cannot be covered with timber boarding; in this case tiles are placed on the rafters which are placed parallel to the long side of the roof directly. The roof construction usually cannot be seen inside the rooms since the ceiling of the room is covered with timber boarding; this coating layer is supported by ceiling joists similar with the floor joists. The ceilings of the important rooms are usually ornamented. The moldings are used in the connections of wall and ceiling surfaces. 

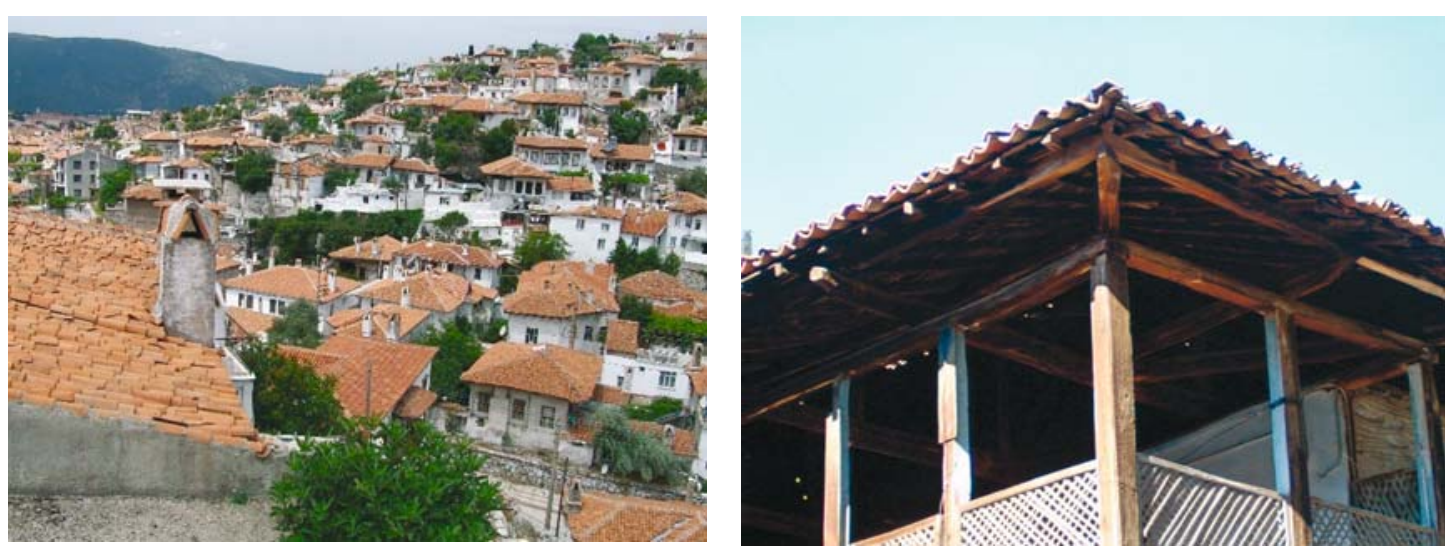

Fig. 10. Roof typology of Muğla settlement (left), Roof construction of a Birgi House (right)

One of the main criteria that affected the traditional construction technology in the region were the earthquakes. From seismic design point of view, the diagonal members are the most important elements of the structure. To provide the overall ductility of the system and energy absorption capacity, the braces should be properly constructed. The lack of these elements in the frame parallel to the main earthquake direction causes partial or total collapse of the structure [7]. Another important issue emphasized in the study by A. Er Akan is the loss of the techniques used in the traditional timber structures. But it is concluded that there are still several characteristics of these structures some of which can offer the key for new earthquake resisting structure. "In an earthquake, only one thing is important that is the strength and ductility of structure. Therefore, for designing a structure in earthquake zone architects should be aware of the dynamics of the seismic behaviour. According to researchers earthquakes have shaped the traditional timber structures in the past. Therefore, people can learn many things from the traditional construction techniques."

In other words, instead of condemning the houses built with traditional timber construction system without a detailed examination or built new buildings instead, it will be reasonable to evaluate their-strong and weak points in accordance with the current architecture and technique (standard and the regulations) and to see them as an alternative solution to the house production which increases quickly today. This information is important primarily to prevent the loss of lifes and property during the earthquakes to come [8].

Tobriner, also evaluates the seismic performance of Turkish houses and emphasizes the importance of proper diagonal braces: "Turkish houses have features which unite them with antiseismic construction elsewhere. The most obvious is that they are made of wood. The property of wood to be flexible without breaking and to return after bending to its former shape makes it an ideal construction material in earthquake country. If beams and columns are sufficiently strong and flexible, braced and tied together to work as units, wooden walls can resist the lateral forces induced by earthquakes. Although the spaces between the timber frame may be filled with adobe, brick or simply left vacant, the wooden skeleton of the Turkish house can stand on its own as a self-supporting system. The timbers are simply nailed together but the framework is stabilized by the use of diagonal braces" [9]. 


\section{CONCLUSION}

Wooden material is described as the oldest construction material alongside stone. In the historical process, especially for the buildings of shelter, timber construction components are seen to be used as primary and indispensable structural system components in different geographies of the world. In different regions, the traditions can lead to differentbuilding components, construction techniques, and spatial organizations and even artistic elements and make the unique examples of region. Turkey also has a significant repository of vernacular regions and architecture. The traditional architecture of Anatolia and the "timber construction"components are subjects of many considerable research and documentation works. However, every region has its own architectural and structural characteristics. In the study, traditional housing technology and the use of timber componentsin Western part of the Anatolia are presented for proper understanding of the construction system.

Because it is inevitable to make various intervention to the buildings during the process of protecting the cultural heritage. In this sense, the intervention to be made to the structural system of the construction will naturally allow the entire building maintenance. In order to perform a correct application and detailing during the process of repairing and/or restoration, the current system must be analyzed very well. Proper understanding of the details and the construction system will prevent the wrong intervention and the buildings will be able to transfer all architectural and cultural values they have for the future.

Another revenue of the traditional construction systems, that is examined in the paper, is the criteria gained through centuries using trial and error and to be used in the construction process of new buildings that may be ordered as below:

- Compatibility to the regional conditions (environmental conditions, climate, geological structure, topographic properties etc.);

- Effective use of the material;

- Flexibility (spatial and structural);

- Adaptation to the local life style and cultural diversity (Intimacy requirements, forming according to the traditional production types etc.);

- Neutrality and Simplicity (Forming the architecture by the life style, use of natural and eco-friendly construction material and components etc.);

- Realism (The architecture formed by income level and social structure of the family, selection of detail and material use etc.).

The mentioned criteria created with the analysis of traditional construction methods and systems in reality are among the sub constituents of sustainable construction which is one of the most important titles of today.

By detailed examination and evaluation of the positive and negativefacts of traditional timber frame techniques in accordance with the current architectural and engineering standards some data on construction techniqes can be obtained. These data also can be used to create alternative solutions to the house productionof today.

Another important point is to have sufficient information regarding the earthquakebehaviors of the timber buildings located in the earthquake zone. In addition, implementing detailed works regarding the earthquake behaviorin order to transmit our cultural heritage to the next generations will be beneficial in terms of the economy of the country. 


\section{REFERENCES}

[1] R. Hughes, «Hatıl Construction in Turkey,» \%1 içinde Earthquake-Safe:Lessons To Be Learned From Traditional Construction International Conference On The Seismic Performance Of Traditional Buildings, İstanbul, 2000.

[2] S. H. Eldem, Türk Evi I (Turkish House I), İstanbul: TAC Vakfi, 1984.

[3] R. Bozer, Kula Evleri (Kula Houses), Ankara: Kültür ve Turizm Bakanlığg (Ministry of Culture and Tourism), 1988.

[4] E. Aladag, Mugla Evi (Mugla House), Mugla: Hamle Yayınevi, 1991.

[5] M. M. Gül, "Birgi geleneksel yerleşim dokusunun koruma ilkeleri açısından değerlendirilmesi," Mimar Sinan University, School of Natural and Applied Sciences), İstanbul, 1995.

[6] M. Tanac and Ö. Yılmaz Karaman, "Wooden Load Bearing Structural Elements of Kula Traditional Houses Case Study of Zabunlar and Goldeliler Houses," in Wood science for conservation of cultural heritage - Proceedings of the International Conference Held by Cost Action IE0601 in Braga (Portugal) 5-7 November 2008, Florence, 2010.

[7] A. Er Akan, "Some Observations on the Seismic Behaviour of Traditional Timber Structures in Turkey," METU- The Graduate School of Natural and Applied Sciences, Ankara, 2004.

[8] A. Doğangün, R. Livaoğlu, İ. Tuluk and R. Acar, "Geleneksel Ahşap Yapıların Deprem Performanslar1,” in Proceedings of International Earthquake Symposium 2005, Kocaeli, 2005.

[9] S. Tobriner, "Wooden Architecture and Earthquakes in Istanbul; A Reconnaissance Report and Commentary on the performance of wooden structures in the Turkish earthquakes of 17 August and 12 November 1999," United Nations Centre for Regional Development, Disaster Management Planning, Hyogo Office, Kobe, 2000.

Web 1: Credit For Figure 3- Log House:

http://4.bp.blogspot.com/-CxGq-_TdgZU/T4XxNJXoTuIAAAAAAAAA1o/8V6Cloxa2rc/s1600/ DSC01331.jpg 